failed to show cycasin (Table $2 A$ ). Prolonged boiling did not reveal any cycasin as it had already been destroyed.

Further indirect confirmation of the foregoing observations, on the varying content of cycasin and the effect on it of boiling and storing, emerged from our long-term experiments on the feeding of various preparations of cycad nuts to different groups of monkeys. Two of three animals fed on the nut, after it had been intensely boiled, died of jaundice and hepato-toxicity while only one out of five monkeys fed on unwashed cycad suffered this fate (unpublished observations).

This investigation was supported in part by a grant from the National Multiple Sclerosis Society of America.

Indian Council of Medical Research, DARAB K. DASTUR RAM S. PALEKAR Neuropathology Unit,

Post-Graduate Research Laboratories,

J. J. Group of Hospitals, Bombay 8.

1 Palekar, R. S., and Dastur, D. K., Nature, 206, 1363 (1965).

" Riggs, N. V., and Korseh, B. H., Second Conf. Identification of Toxic Elements of $\ddot{C} y c a d s$, National Institutes of Health, Aug. 1962; mimeograph, Appendix 6,103 .

"Matsumoto, H., and Strong, F. M., Arch. Biochem. Biophys., 101, 299 (1963).

${ }^{4}$ Nishida, K., Kobayashi, A., and Nagahama, T., Bull. Agr. Chem. Soc., Japan, 19, 77 (1955).

${ }^{5}$ Nishida, K., Kobayashi, A., and Nagahama, T., Bull. Agr. Chem. Soc., Japan, 19, 172 (1955).

- Dastur, D. K., Proc. Third Conf. Toxicity of Cycads, Fred. Proc., 23, 1368 (1964)

Keresztesy, J. C., Second Conf. Identification of Toxic Elements of Cycads, National Institutes of Health, Aug. 1962; mimeograph, 6 .

Armstrong, E. F., and Armstrong, K. F., The Glycosides: Monographs on Biochemistry (Longmans Green and Co., London, 1931).

- Matsumoto, H., Second Conf. Identification of Toxic Elements of Cycads, National Institutes of Heaith, Aug. 1962, mimeograph, 46 .

\section{Red Fluorescence in Costo-vertebral Spot of Hamsters}

DURING the course of experimental production of melanomata in hamsters ${ }^{1,2}$ and the study of red fluorescence in tumours ${ }^{3,4}$, we discovered, by chance, that the costo-vertebral spot of some of our normal hamsters showed a well-marked red fluorescence under ultra-violet radiation. Red fluorescence has been observed in the Harderian gland of hamsters and some other rodents ${ }^{5}$, but its significance is obscure. Red fluorescence is also seen in many tumours ${ }^{3,4}$. In all these cases the red fluorescence is due to the presence of porphyrins.

Fifty males and fifty females from our colony of hamsters, in which the exact date of birth was known, were shaved in the region of costo-vertebral spots and examined under ultra-violet radiation. This was done in the autumn (23.10.64) when the animals were between 5 and 18 months old. Only one male showed red fluorescence in one of its costo-vertebral spots. Twenty-one males and twelve females from the same group of animals were shaved and re-examined in the following summer (19.5.65). (The romaining animals were not available because they had been used for other experiments.) The age of the animals used in this experiment ranged from 11 to 15 months. Of the females, only one animal showed a weak reddish fluorescence in one of the costo-vertebral spots, but sixteon males showed fluorescence in both spots, two in one spot, and three showed no red fluorescence. Even in males showing red fluorescence in both spots, one spot was usually more strongly fluorescent than the other.

Histological examination of cryostat prepared sections under ultra-violet radiation showed that the red fluorescence is mainly located in the necks of the hair follicles above the large sebaceous-type gland that occurs in this region. At times a faint patchy red fluorescence was also seen in the adjacent sebaceous glands themselves.

Red fluorescence in biological material is due to the presence of porphyrins. It would therefore appear that the male hamster in the summer season produces a secretion containing porphyrins from the glands in the costovertebral spot. It has been suggested that the secretion from the spot of the male hamster serves to mark territory ${ }^{6}$, but that from the female has no such function. It is intriguing to speculate whether this difference is due to the presence of porphyrins. As yet, little is known about the fluorescence of the secretion of other territory-marking animals.

\section{Department of Pathology,}

O. IlLLMaN

University of Sheffield.

${ }^{1}$ Ghadially, F. N., and Barker, J. F., J. Path. Bact., 79, 263 (1960).

${ }^{2}$ Illman, O., and Ghadially, F. N., Brit. J. Cancer, 14, 483 (1960).

${ }^{3}$ Ghadially, F. N., J. Path. Bact., 80, 345 (1960).

"Ghadially, F. N., Neish, W. J. P., and Dawkins, H. C., J. Path. Bact., 85, 77 (1963).

5 Figge, F. H. J., Cancer Res., 4, 465 (1944).

' Lochbrunner, A., Zool. Jahrb. Abt. allg. Zool. u. Physiologie d. Tiere, 66, $389(1956)$

\section{HAEMATOLOGY}

\section{Effect of Ferritin on Globin Synthesis}

IN certain hypersideraemic anaemias the erythroid precursor cells in the bone marrow contain iron deposits. The iron overloaded mitochondria of these sideroblast are not capable of synthesizing haem at a normal rate ${ }^{1}$ Iron-containing deposits are demonstrable not only in mitochondria, but also in other parts of the cytoplasm of these cells. It is, therefore, possible that iron overload also affects globin synthesis directly. In $\operatorname{som} \theta$ of these hypersideraemic anaemias pyridoxine has been found to have a therapeutic effect which is likely to be due to the mobilization of the mitochondrial iron deposits ${ }^{1}$. In view of the amelioration of the anaemia of thalassaemia with pyridoxine ${ }^{2}$, a direct influence of this vitamin on globin synthesis might also be assumed.

The effect of ferritin on globin synthesis was investigated in a cell-free system meant to imitate the conditions in sideroblasts. Reticulocytes, obtained from phenylhydrazine-treated rabbits, were lysed by short exposure to hypotonic tris chloride buffer containing magnesium chloride (ref. 3). The stroma, mitochondria, and intact leucocytes were removed by centrifugation at $15,000 \mathrm{~g}$ for $15 \mathrm{~min}$. Ribosomes and the enzyme fraction were then obtained and processed according to the method of Allen and Schweet ${ }^{4}$ with the following exceptions: $s$ RNA was not separated from the enzyme fraction; valine-1. ${ }^{14} \mathrm{C}$ was used and the incubation period was $40 \mathrm{~min}$. To some of the incubation mixtures (Table 1) commercial, 2x crystallized, cadmium-free ferritin was added which had been dialysed against $0.05 \mathrm{M}$ tris chloride buffer, $p \mathrm{H} \quad 7.5$. Experiments were also done with the addition of buffered pyridoxal, pyridoxine, pyridoxamine, or deoxypyridoxine in concentrations from $10 \mathrm{~m} \mu \mathrm{g}$ to $1 \mathrm{mg}$ per tube.

After incubation the ribosomes and, when present, most of the ferritin were removed by centrifugation at $100,000 \mathrm{~g}$ for $2 \mathrm{~h}$. The supernate was freed of unincorporated valine-1-14 $\mathrm{C}$ by dialysis against running tap water for $36 \mathrm{~h}$. Aliquots of the dialysed samples were then dissolved in hydroxide of hyamine and added to naphthalenedioxane scintillation fluid $^{5}$. Radioactivity was deter-

Table 1. The TFFect of Ferritin on Globin SxNthisis with Variations IN THE COMPOSITION OF THE INCUBATtON MiXTURE

$$
\begin{array}{lcc}
\text { Tube content } & \begin{array}{c}
\text { Without ferritin } \\
\text { (c.p.m./tube) }
\end{array} & \text { With } 10 \mathrm{mg} \text { ferri- } \\
\text { tin (c.p.m./tube) }
\end{array}
$$

Standard mixture*

Standard mixture, double enzyme Standard mixture, double ${ }^{14} \mathrm{C}$-valine tandard mixture, double energy $\dagger$ Standard mixture, double GSH (c.p.m./tube)

$\begin{array}{ll}1,703 & 473 \\ 3,268 & 795 \\ 1,797 & 997 \\ 1,315 & 584\end{array}$

* $3 \mathrm{mg}$ ribosomes; $5 \mathrm{mg}$ enzyme; 1 umole ATP; $120 \mu \mathrm{g}$ pyruvate kinase: 10 moles 10 moles phosphoenolpyruvate; $20 \mu$ moles GSH; $50 \mu$ moles potassium amino-acid mixture (3) $10 \mu$ chloride; $0 \cdot 25 \mu$ moles $6 \mathrm{TP} ; 0 \cdot 05 \mathrm{ml}$. of amino-acid mixture $(3) ; 10 \mu \mathrm{g} D, \mathrm{~L}-\mathrm{Tal}$
buffer, $p$ H $7 \cdot 5$; total volume $1 \cdot 45 \mathrm{ml}$.

† $2 \mu$ moles ATP; $240 \mu \mathrm{g}$ pyruvate kinase; 20 moles phosphoenolpyruvate. 